\title{
TRICHODINA GOBII (CILIOPHORA: TRICHODINIDAE) ON WHITING MERLANGIUS MERLANGUS WITH A CHECKLIST FROM TURKISH AND RUSSIAN COASTS OF THE BLACK SEA
}

\author{
Ahmet ÖZer ${ }^{1}$, Türkay ÖZtürk ${ }^{1}$, Yulia M. KornyYchuK ${ }^{2}$ and Violetta Yurakhno ${ }^{2}$ \\ ${ }^{1}$ Sinop University, Faculty of Fisheries and Aquatic Sciences, 57000 Sinop, Turkey \\ E-mail:aozer@sinop.edu.tr \\ ${ }^{2}$ A. O. Kovalevsky Institute of Biology of the Southern Seas \\ 2 Nakhimov av., 299011 Sevastopol, Russia; E-mail: juliakorniychuk@gmail.com
}

Trichodina gobii was identified during a parasitological survey conducted on the parasite fauna of whiting, Merlangius merlangus at both Sinop (Turkey) and Sevastopol (Russia) coasts of the Black Sea in the period between May 2011 and March 2014. Its morphological characteristics and taxonomic affinities with other previous reports on this species were revealed. The ecological occurrences in relation with seasonality, host length and sex of whiting were also determined. Parasitological indices were calculated from 690 and 423 whiting specimens collected in Sinop and Sevastopol, respectively. Overall infestation prevalence (\%) and mean intensity and mean abundance values were $45.6 \%, 70.1 \pm 10.4$ and $32.0 \pm 4.9$, respectively, in Sinop, while they were $6.9 \%, 29.2 \pm 10.1$ and $2.0 \pm 0.8$ in Sevastopol. The taxonomic affinities to other trichodinid species and ecological data are discussed in detail.

Key words: Trichodinid, marine fish, season, checklist.

\section{INTRODUCTION}

Whiting, Merlangius merlangus (Linneaus, 1758), is a gadid fish with a geographical distribution in the northeast Atlantic from the southern Barents Sea and Iceland to Portugal, and in the Black, Adriatic and Aegean Seas (FroESE \& PAULy 2009). In the Black Sea, whiting is one of the main commercially significant fish species in Turkey and it is common near western Turkish coasts including Sinop; annual catch was 7367 tonnes in 2012 in Turkey (TÜIK 2013).

Species of the genus Trichodina Ehrenberg, 1838 are among the most frequently encountered ciliates on marine and freshwater animals, typically fishes, molluscs, as well as amphibians. To date, about 300 nominal trichodinid species have been reported from different environments in the world (TANG \& ZHAo 2013). However, a total of 22 species belonging to genus Trichodina have so far been reported from the Black Sea (see Table 1). In Turkey, the trichodinid ciliates of freshwater fishes have received considerable attention in recent years (Özer \& Erdem 1998,Özer 2000, 2003a,b, 2007, Özer \& Öztürk 2004, 
ÖĞÜT \& PALm 2005, ÖztürK \& Özer 2007, 2008, ÖztüRK \& ÇAm 2013). Trichodinids infest many fish species with varying intensities dictated by ecological conditions such as temperature and host factors such as sex and length of fish (Özer \& ERdem 1999, Özer 2007). Host specificity in trichodinids appears variable, with species such as Trichodina acuta Lom, 1961, Trichodina nigra Lom, 1960,T. fultoni Davis, 1947 and T. heterodentata Duncan, 1977 in fresh water and T. rectuncinata Raabe, 1958 and T. ovonucleata Raabe, 1958 infecting a large number of marine host species and species such as T. tenuidens Faure-Fremiet, 1944 in fresh water and T. jadranica Raabe, 1958 parasitizing only a couple of marine host species (ÖZER 2003a, ÖZtürk \& ÖZER 2008, PAduA et al. 2012, VALLADÃo et al. 2013). Moreover, Trichodina puytoraci Lom, 1962 and T. lepsii Lom, 1962 have been reported from only mugilids, such as the striped mullet, Mugil cephalus Linneaus, 1758, and the golden grey mullet, Liza aurata Risso, 1810 in brackish water (Byкоvsкaya-Pavlovskaya et al. 1964, Kinne 1984, Grupcheva et al. 1989, Özer \& Öztürk 2004, Özer \& YILMAz KIRCA 2013). XU (2007) made detailed revision on the identification of T. gobii Raabe, 1959, previously reported either T. domerguei gobii or T. jadranica by some authors (RAABE 1959, Lom 1970, Grupcheva et al. 1989, Su \& White 1995, Madsen et al. 2000), summarized its host range and suggested that $T$. gobii is a widely distributed species that belonged to one of the extraordinary fish trichodinids occurred in both marine and freshwater environments.

Although infestations by trichodinid ciliates have previously been reported from marine fishes in the Black Sea (Table 1), there is only a limited number of studies present on the trichodinid fauna of whiting elsewhere in the Black Sea including Turkish and Russian coasts. In the present study, the whiting, M. merlangus, inhabiting Sinop and Sevastopol coastal zones at southern and northern Black Sea were investigated in order to determine its trichodinid fauna and its affinities with seasonality, length and sex of host fish, as well as the host-parasite relationships of trichodinid parasites.

\section{MATERIAL AND METHODS}

Whitings were collected throughout a period from May 2011 to March 2014 from local fishermen. A total of 690 fish specimens near Sinop, Turkey and 423 specimens near Sevastopol (Balaklava Bay), Russia were examined for parasites (Fig. 1). Collected fish were transferred to parasitology laboratory on dried ice and examined for parasites using conventional methods. Trichodinids were determined by screening smears of skin, fins and gills of fish using a light microscope and full parasite count was conducted one by one to obtain the exact number rather than estimate. Dry smears were made in accordance with Klein's silver nitrate $\left(\mathrm{AgNO}_{3}\right)$ method (Lom \& Dykova 1992). All parasite species were identified using a phase contrast Olympus microscope (BX53) equipped with a digital camera (DP50) and hand drawing attachment. The measurements were carried out using an ocular micrometer. The description was based on 30 specimens. Arithmetic 


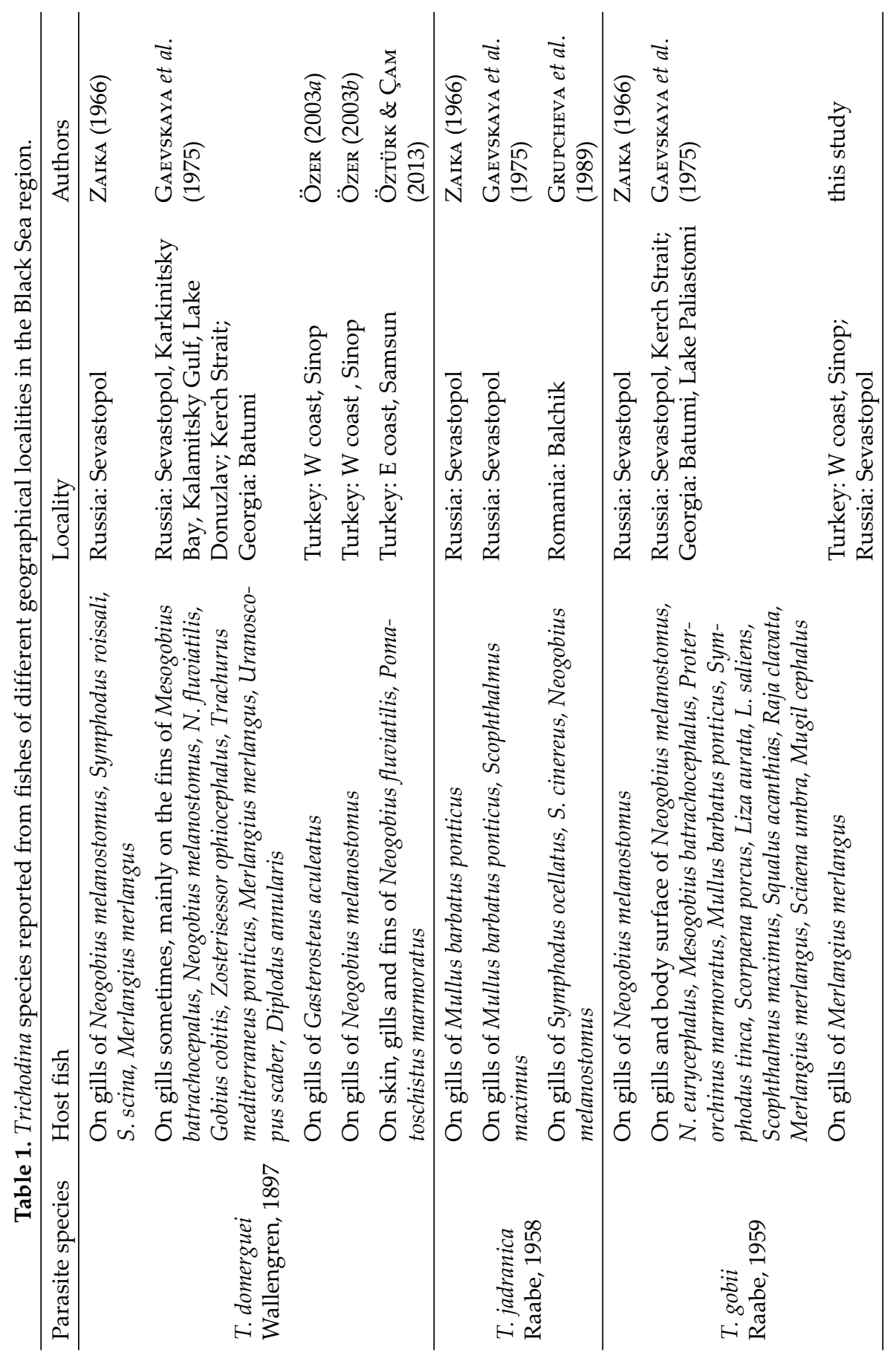




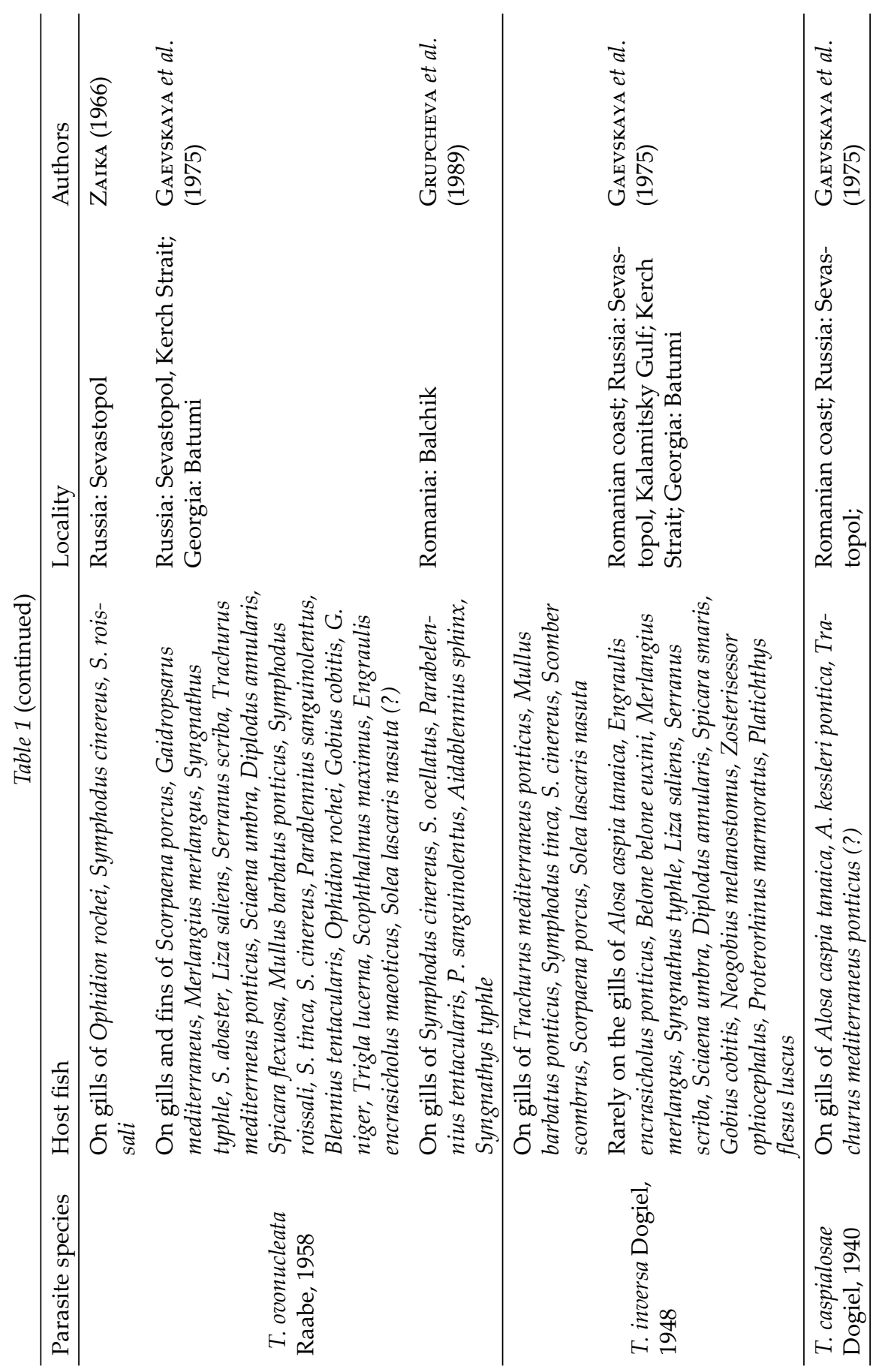




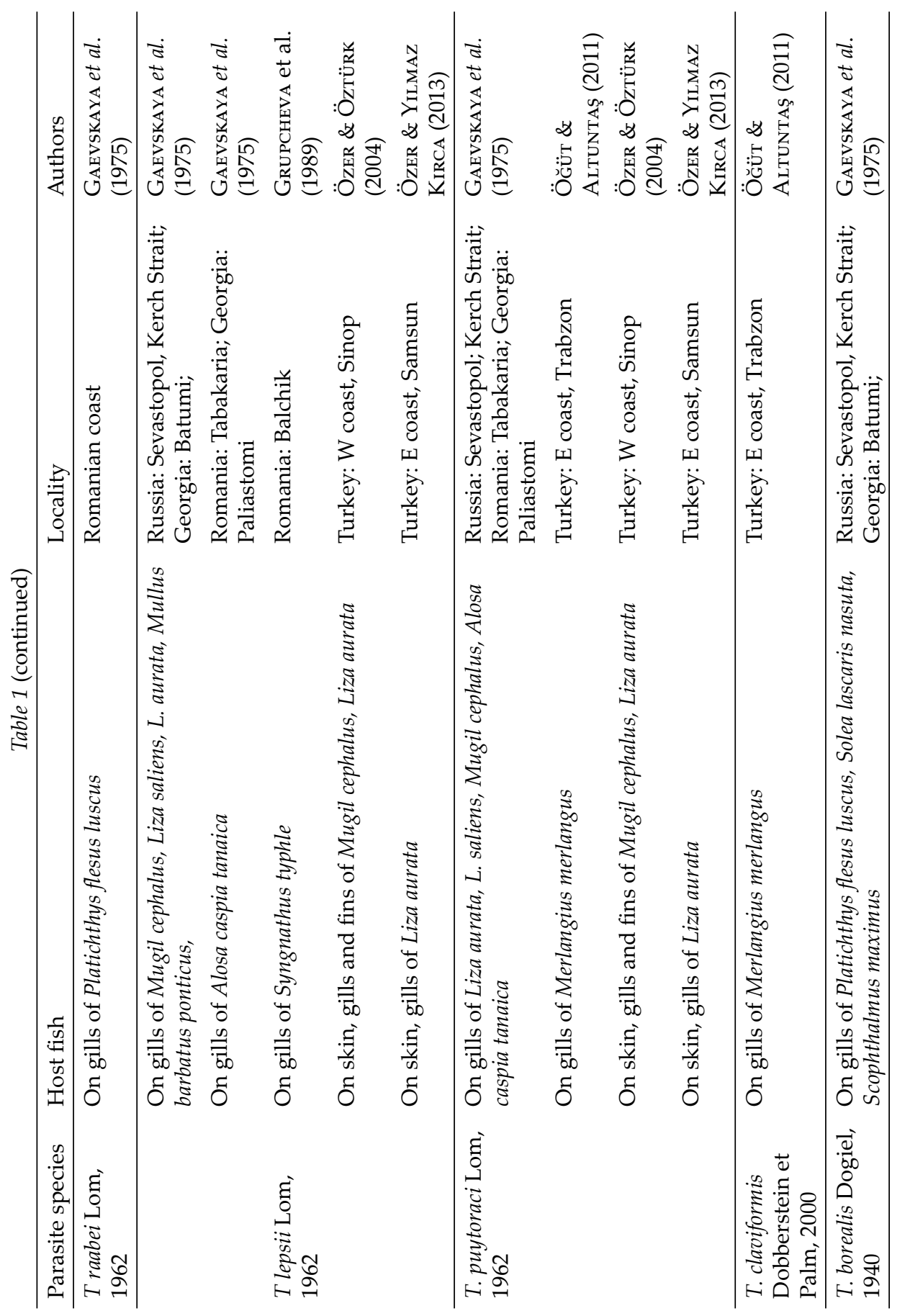




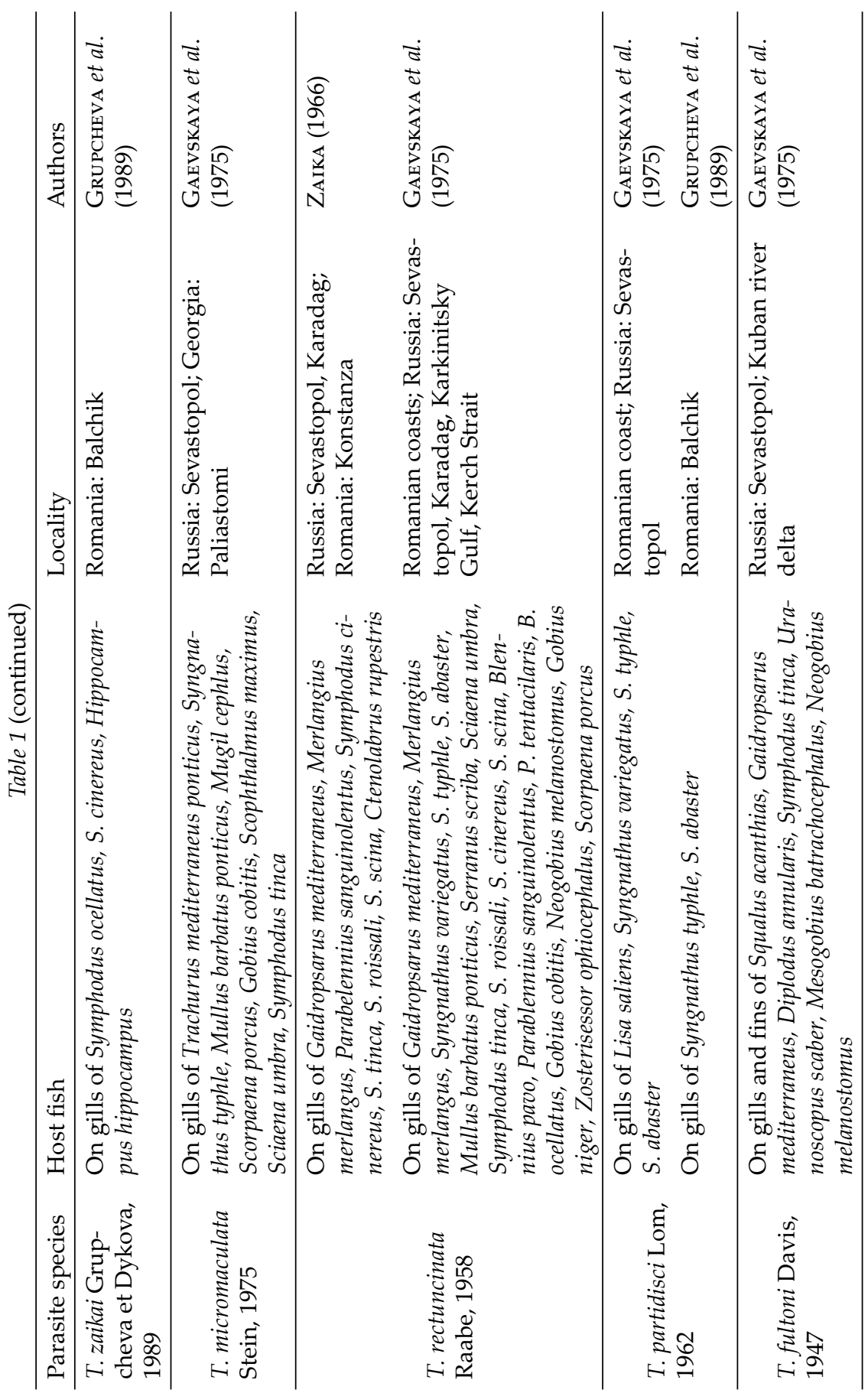




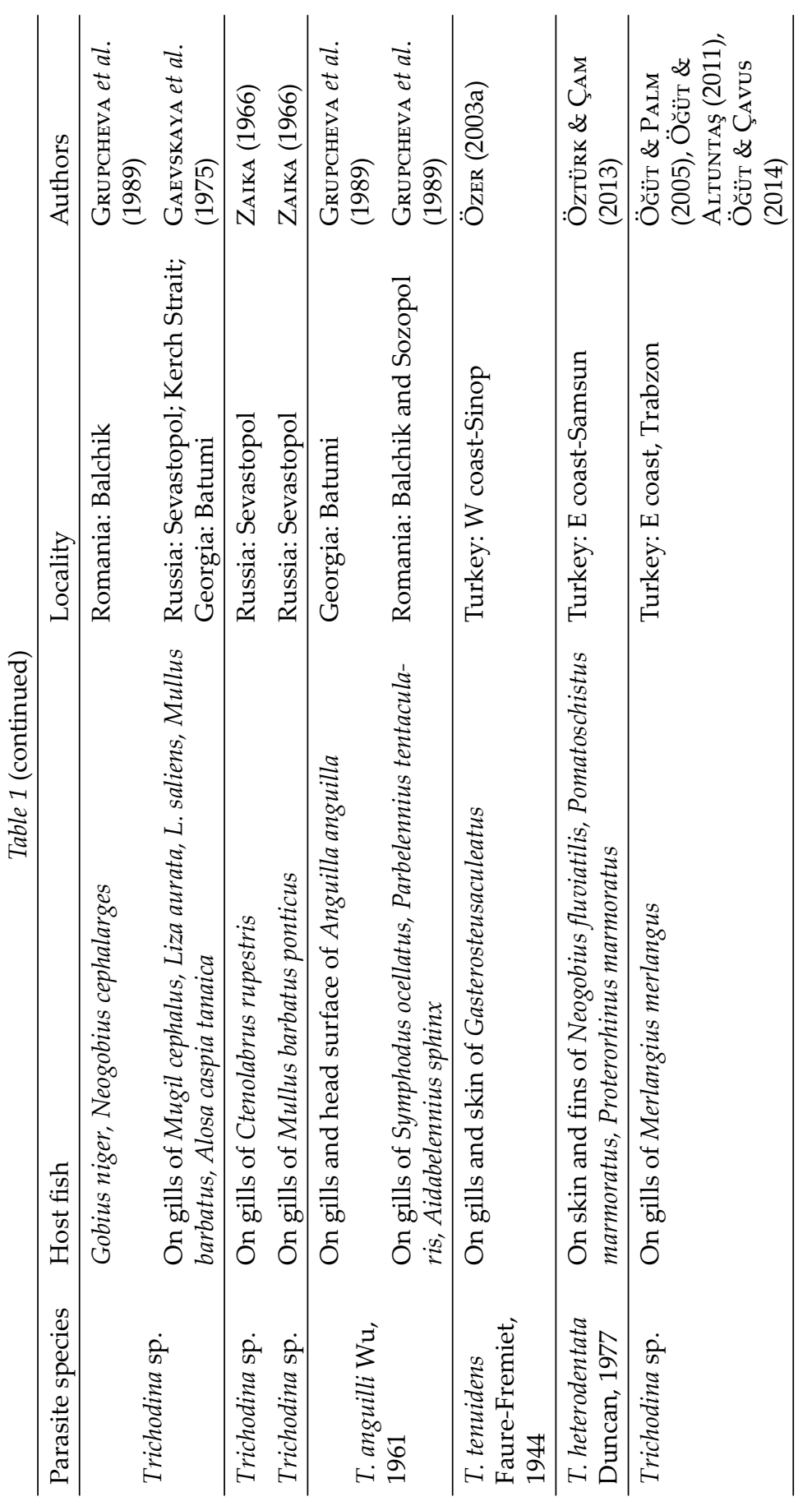


means \pm standard error is followed, in parentheses, by the minimum and maximum values. Morphometric measurements of the individual parasites were conducted according to Lom and Dүкоva (1992). Detailed descriptions of trichodinid denticles are presented in accordance with the method proposed by VAN As and BAssON (1989). The span of the denticle was measured from the tip of blade to the tip of ray. However, denticle length was measured as described by Lом and Dyкоva (1992). Prevalence (\%), mean intensity and mean abundance values were determined according to Bush et al. (1997). Water temperature $\left({ }^{\circ} \mathrm{C}\right)$ values were measured monthly using a YSI Professional Plus water quality instrument.

Kruskal-Wallis test (Nonparametric ANOVA) was performed to find out the significant differences in the mean intensity values of the trichodinid for length classes of fish as well as for the seasons. The difference between parasite loading on male and female whiting was tested by the Mann-Whitney U-test. All the statistical tests were performed at the significance level of $5 \%$.

\section{RESULTS}

Trichodina gobii Raabe, 1959 was the only trichodinid species identified on the gills of $M$. merlangus from the both southern and northern parts of the Black Sea (Fig. 2, Table 2). This study also revealed comparable data on its seasonality and host-parasite relationship at both sampling localities (Fig. 1, Table 3). Surface water temperature $\left({ }^{\circ} \mathrm{C}\right)$ values at both sampling localities were presented in Table 4.

\section{Morphological characteristics of Trichodina gobii}

A medium-sized trichodinid with disc-shaped body (Fig. 2A-E). The centre of the adhesive disc of the specimens impregnated with silver nitrate is clear with several dark granules. The almost sickle-shaped blade of denticle is broad

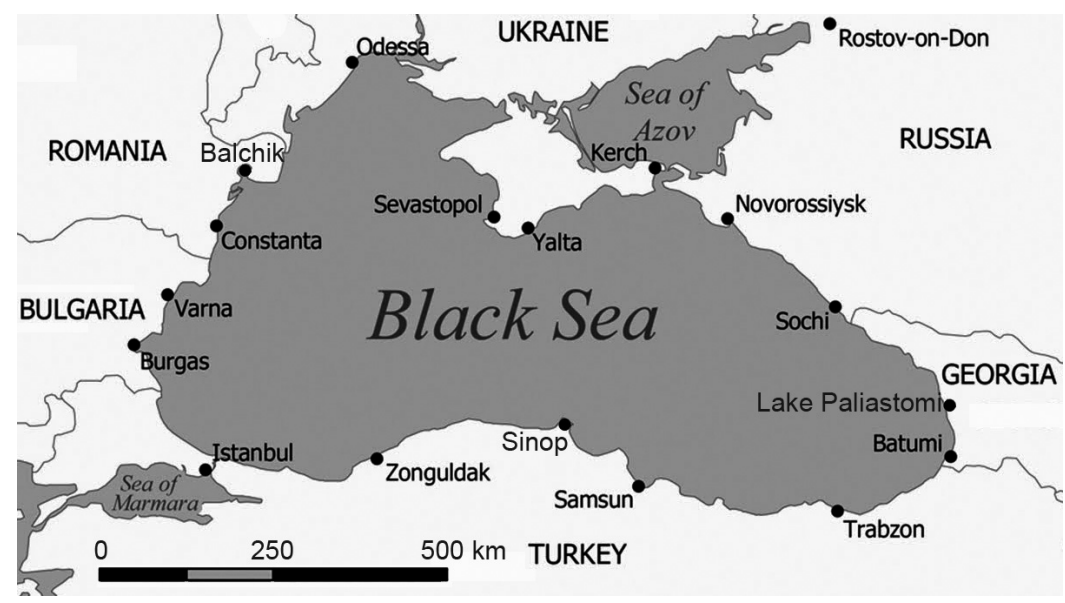

Fig. 1. Map of sampling localities at the Black Sea. 
Table 2. Morphometric data of Trichodina gobii collected from gills of Merlangius merlangus (Sinop, Western Black Sea).

\begin{tabular}{lc}
\hline Body diameter $(\mu \mathrm{m})$ & $37.5 \pm 1.1(34.0-42.0)$ \\
Adhesive disc diameter $(\mu \mathrm{m})$ & $29.9 \pm 0.4(29.0-34.0)$ \\
Border membrane width $(\mu \mathrm{m})$ & $2.3 \pm 0.1(2.0-3.0)$ \\
Denticle ring diameter $(\mu \mathrm{m})$ & $20.0 \pm 0.4(18.0-22.0)$ \\
Denticle number & $22(21-25)$ \\
Number of radial pins/denticle & $7(7-8)$ \\
Denticle span $(\mu \mathrm{m})$ & $9.7 \pm 0.2(8.5-11.0)$ \\
Denticle length $(\mu \mathrm{m})$ & $4.6 \pm 0.1(4.0-5.0)$ \\
Blade length $(\mu \mathrm{m})$ & $3.9 \pm 0.1(3.5-4.5)$ \\
Thorn length $(\mu \mathrm{m})$ & $4.1 \pm 0.1(3.5-5.0)$ \\
Central part width $(\mu \mathrm{m})$ & $1.7 \pm 0.1(1.5-2.0)$ \\
\hline
\end{tabular}

filling more than half of the area between $\mathrm{Y}$ axis. The distal margin of blade almost touches the border membrane. The apex of blade is absent. Tangent point of blade is lower than distal blade surface. Posterior blade margin fairly slightly curved. Blade apophysis absent. Blade connection thick. Central part well developed, but thick and long tapering to rounded point fitting sligthly into preceding denticle. Ray connection robust and thick. Ray apophysis present in some specimens. Base of ray thick, on with ray tapering gradually to rounded point. Rays long and curved in anterior direction with tips touching $\mathrm{Y}$ axis. Ratio of denticle above and below $\mathrm{X}$ axis about unity (Table 2).

Infestation indices of Trichodina gobii on $\mathrm{M}$. merlangus

Trichodina gobii infested only the gills of $M$. merlangus at both sampling localities. Overall infestation prevalence (\%), mean intensity and mean abun-
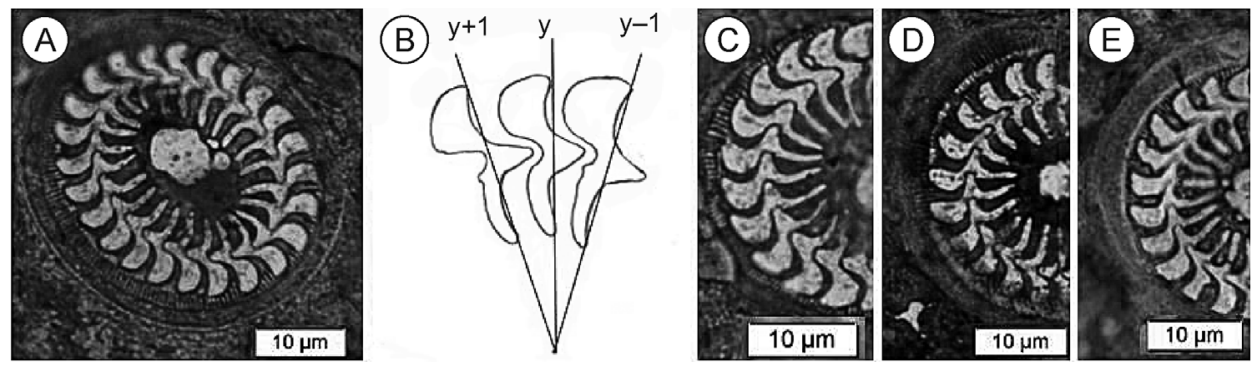

Fig. 2. Trichodina gobii. $\mathrm{A}=$ photomicrograph of silver impregnated parasite, $\mathrm{B}=$ diagrammatic drawing of the denticles, $\mathrm{C}-\mathrm{E}=$ morphological variabilities indicating slightly different blade shapes. 


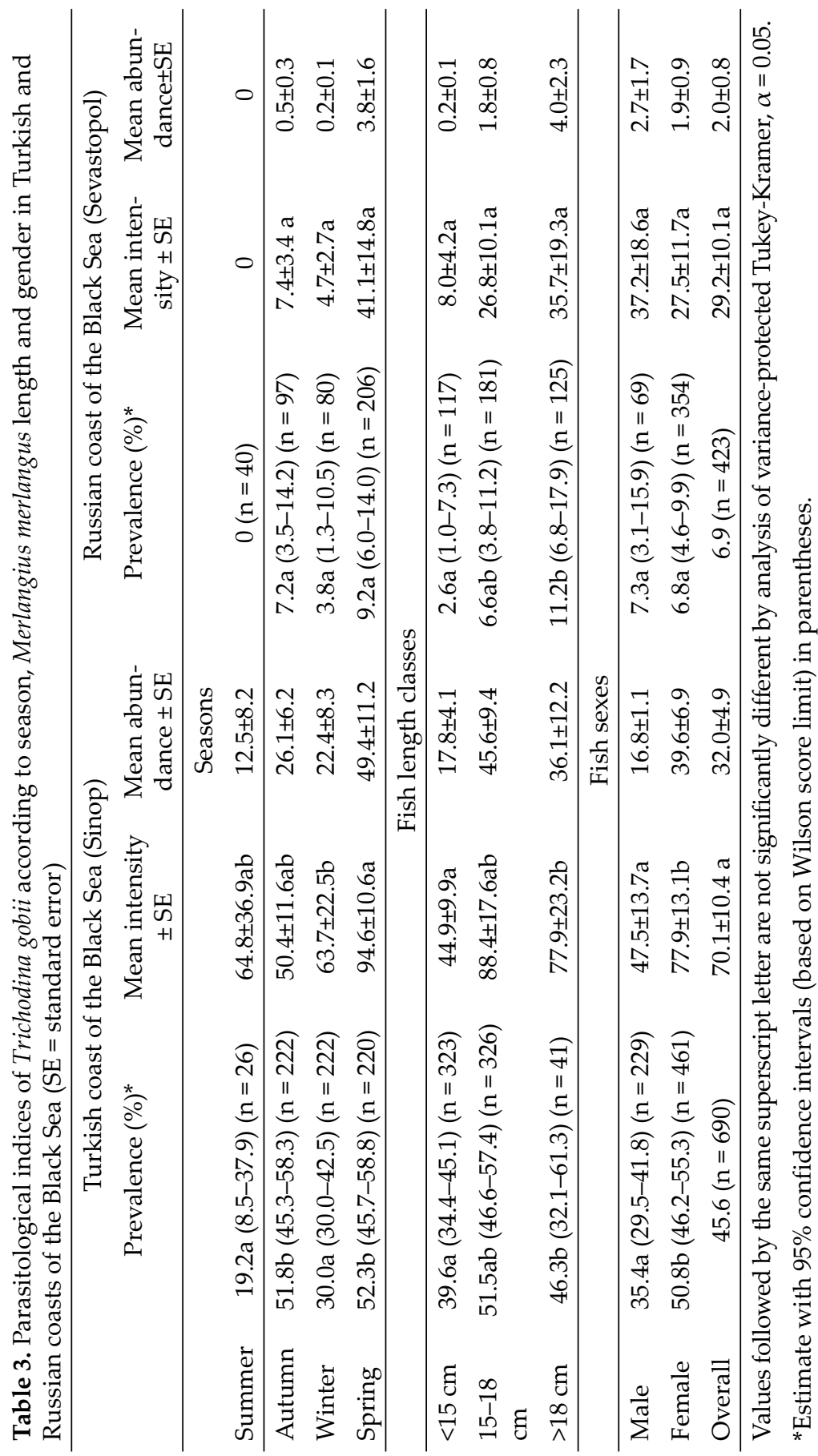


Table 4. Seasonal surface water temperature ranges measured at both sampling localities during one year period in 2012-2013.

\begin{tabular}{lcc}
\hline Season & \multicolumn{2}{c}{ Temperature $\left({ }^{\circ} \mathrm{C}\right)$} \\
\cline { 2 - 3 } & \multicolumn{1}{c}{ Sinop } & Sevastopol \\
\hline Spring (March-May) & $9.5-17.2$ & $8.4-16.4$ \\
Summer (June-August) & $20.4-26.1$ & $21.7-25.2$ \\
Autumn (September-November) & $15.2-21.4$ & $13.9-21.6$ \\
Winter (December-February) & $8.3-13.1$ & $8.2-11.0$ \\
\hline
\end{tabular}

dance values determined in Sinop were $45.6 \%, 70.1 \pm 10.4$ and 32.0 44.9 ,respectively and $6.9 \%, 29.2 \pm 10.1$ and $2.0 \pm 0.8$, respectively in Sevastopol (Table 3). These values were also recorded for seasons as well as for the sex and length classes of M. merlangus (Table 3). Infestation prevalence (\%) and mean intensity values were higher in spring, middle length class of fish and female specimens and statistically different between seasons, sex and length classes of fish $(\mathrm{P}<0.05)$ in Turkish samples (Table 3$)$. On the other hand, infestation prevalence $(\%)$ and mean intensity values were higher in spring, middle length fish class and male specimens and no statistically significant differences between the three length classes, sex of fish and seasons in Russian samples $(P>0.05)$ (Table 3). When compared each data between sampling localities, despite 5 to 7 times higher infestation prevalence values in Turkish samples than those in Russian samples, no statistically significant differences were determined between both sampling localities $(\mathrm{P}>0.05)$ (Table 3$)$.

\section{DISCUSSION}

A total of 21 Trichodina species have so far been reported from the Black Sea fishes and only 6 of them (T. domerguei, T. rectuncinata, T. gobii, T. puytoraci, T. claviformis, T. inversa) are from whiting M. merlangus (Table 1). Our parasite was identified as Trichodina gobii Raabe, 1959 based on both morphological features and morphometric measurements (Fig. 2, Table 2) when compared with other previously recorded Trichodina species from fishes in the Black Sea and from other fish species reported to be infested by above mentioned Trichodina species by several authors from other localities (XU 2007, YEMmEN et al. 2010, 2012). ÖĞüT and PALm (2005), ÖĞüT and Altuntaş (2011) and ÖĞüT and ÇAvuş (2014) reported Trichodina sp. on the gills of M. merlangus at the eastern part of Turkish Black Sea coasts and we believe that the morphology and morphometric data provided for this parasite correspond to Trichodina gobii. $\mathrm{X}_{\mathrm{U}}$ (2007) provided a brief history on T. gobii, a species named as Trichodina domerguei f. gobii at first, elevated to species rank based on current literature 
and made a revision of T. jadranica and indicated that it had some varieties in morphological features due to its occurrence on several fish species in marine and freshwater environments.

Since the original description of T. gobii from Gobius minutus in the Black Sea by RAABE (1959), data on its ecological and host-parasite relationship are very limited (Yemmen et al. 2012, ÖĞüt \& ÇAvuş 2014) thus, this study provides the first and more comparable data on these aspects. Yemmen $e t$ al. (2012) reported prevalences between $5 \%$ and $63.84 \%$,without any intensity values, from the gills of several soleid fish species (Solea solea Quesnel, 1806, S. aegyptiaca Chabanaud, 1927, S. senegalensis Kaup, 1958) in several northern lagoons of Tunisia. In the present study, overall infestation prevalence values of $45.6 \%$ in Turkish coasts and $6.9 \%$ in Russian coasts of the Black Sea suited well in the range reported by YEMMEN et al. (2012) and, however, lower than that of ÖĞüt and ÇAvuş (2014) who reported infestation prevalence over $88.3 \%$ on the gills of M. merlangus at the eastern Turkish Black Sea coasts during January-March period in 2010 and 2011. It is obvious from literary data (see $\mathrm{X}_{\mathrm{U}}$ 2007 for details; YeMmen et al. 2012, ÖĞüT \& ÇAvuş 2014) and this study that the gills are the main microhabitat for this trichodinid species.

Seasonal and temperature dependent variations on the occurrence of trichodinids have been shown to occur and spring was reported to be the most favoured season for trichodinid multiplication (ÖZzer 2003a,b, Özer \& ERDEM 1998, 1999, ÖzTüRK \& ÇAM 2013). ÖĞÜT and PALM (2005) reported higher infestation prevalence and mean intensities for Trichodina sp. (syn. of T. gobii) on M. merlangus during the fall, winter and early spring months and indicated strong correlations between prevalence and nitrate, nitrite and phosphate levels. In the present study, both prevalence and mean intensity at both sampling localities had the highest values in spring with statistically significant differences only in Turkish samples. ÖĞüt and PALM (2005) determined infestation prevalence values always stayed above $60 \%$ for Trichodina sp. on M. merlangus throughout a sampling year at the eastern part of the Black Sea, those values in seasonal data of our study never reached to that level. However, a trend for gradual increase in prevalence from late fall up to early spring and then a sharp decrease in summer was very similar at three localities in the Black Sea. On the other hand, mean intensity values of Trichodina sp. (syn. of T. gobii) of ÖĞüt and Altuntaş (2011) were always higher than the mean intensities of our T. gobii as a result of different calculation techniques applied at both studies, full parasite count from all gill arches of fish in the present study and parasite count from only two previously fixed and stained gill arches of fish in the latter. The differences in infestation levels could also be resulted from possible differences in fish stocks, organic pollution and water temperatures at three localities in the Black Sea. ÖzER (2000) reported higher mean intensity value in 
spring for Trichodina mutabilis on wild common carp (Cyprinus carpio L., 1758) than on farmed fish and proposed that the weakened condition of the wild fish was the underlying factor. The increase in our study could be the resulted from the increase in temperature as the protozoan infestations on fish are strongly dependant on the ecological conditions such as temperature and weakened condition matching thebeginning of maturation in whiting during spring.

The number of studies on the existence of trichodinids on both male and female is rare and some reported no statistically significant difference in their existence (ÖzER 2000, 2003b) while some others reported significant differences (ÖZzer 2003a, Öztürk \& ÖZzr 2007). Our data obtained from Turkish and Russian samples somehow correspond well to both situations. Infestation prevalence, mean intensity and mean abundances of female fish in Turkish samples had higher values with statistically significant differences. The situation, however, was the reversed in Russian samples, male fish having higher values though the difference was not statistically significant. Although the analysis of host sex and parasitic infestation does not provide a clear explanations for trichodinid population structures on M. merlangus, it does reveal some patterns that these differences could be resulted from either different fish stocks at both sampling localities or insufficient number of male fish in Russian samples, thus, preventing evaluation on actual effects of fish sex on T. gobii infestations.

The severity of many ectoparasitic infestations increases with host age, possibly as a result of increasing exposure period and host body size (ÖzER 2003b). In the present study, larger-sized whiting had higher infestation indices without any statistically significant differences in Russian samples similar to those of Özer (2003a) for Trichodina domerguei on round goby (Neogobius melanostomus Pallas, 1811) and Öztürk and Özer (2007) for T. domerguei, T. modesta and Tripartiella macrosoma. On the other hand, there is a similarity between Turkish samples in the present study and ÖzER (2003a) for T. domerguei and T. tenuidens on three-spined stickleback (Gasterosteus aculeatus L., 1758) on that the differences in infestation indices on length classes were statistically significant. It must be mentioned that the differences in the mean intensity values of the same length classes on fish at both sampling localities were not statistically significant, despite several folds higher values in favour of Turkish samples. In addition, there was a clear increase in infestation indices of Russian samples as the fish becomes larger, there was a decrease in the largest length class after the middle-size class of $15-18 \mathrm{~cm}$ in Turkish samples. It is generally accepted that as the fish becomes larger, the space for parasite settlement increases. This difference might be a possible result of insufficient number of fish in the largest length class preventing actual evaluation on real effects of fish length on T. gobii infestations in Turkish samples. However, 
some authors attributed the differences in parasite loading to cyclical host changes, a decrease in the number of AB-positive mucous cells resulting from hormonal status of the fish epidermis (Pickering 1977, Pickering \& Christie 1980, Urawa 1992). Further stress on whiting in spring with spawning activity might have occurred. Similar observations were also done when examining fish with mature eggs that corresponded with an increase in the trichodinid number encountered on fish.

In conclusion, T. gobii occurred at higher infestation indices in Turkish whiting samples than those in Russian whiting samples, spring was the most favoured season and larger sized fish had higher prevalence and intensities than that of smaller sized fish at both sampling locations. Females in Turkish samples and males in Russian samples had higher infestation indices.

Acknowledgement - Authors are grateful to the Scientific and Technological Research Council (TÜBITTAK) of Turkey and National Academy of Sciences (NASU) of Ukraine for their financial support to the project number 1100475.

\section{REFERENCES}

Bush, A. O., Lafferty, K. D., Lotz, J. M. \& Shostak, A. W. (1997) Parasitology meets ecology on its own terms: Margolis et al. revisited. Journal of Parasitology 83: 575-583. doi: $10.2307 / 3284227$

Bykovskaya-Pavlovskaya, I. E., Gusev, A. V., Dubinina, N. A., Izyumova, T. S., Smirnova, I. L., Sokolovskaya, G. A., Shtein, G. A., Shulman, S. S. \& Epshtein, V. M. (1964) Key to parasites of freshwater fish of the U.S.S.R. Part I. Translated by Israel Program for Scientific Translations, Jerusalem, Pp.180-218.

Froese, R. \& Pauly, D. (eds) (2009) FishBase. http://www.fishbase.org. [Accessed on 01 February 2014]

Gaevskaya, A. V., Gusev, A. V., Deljamure, S. L., Donetc, Z. S., Iskova, N. I., Kornjushin, V. V., Kovaleva, A. A., Margaritov, N. M., Markevitch, A. P., Mordvinova, T. N., Najdenova, N. N., Nikolaeva, V. M., Parukhin, A. M., Pogoreltceva, T. P., Smogorzhevskaja, L. A., Solonchenko, A. I., Shtein, G. A. \& Shulman, S. S. (1975) Key to parasites of vertebrata of the Black and Azov Seas. Naukova dumka, Kiev, 552 pp. [in Russian]

Grupcheva, G., Lom, J. \& Dyкova, I. (1989) Trichodinids (Ciliata: Urceolariidae) from gills of some marine fishes with the description of Trichodina zaika sp. n. Folia Parasitologica 36: 193-207.

Kinne, O. (1984) Diseases of marine animals. Biologische Anstalt Helgoland, Hamburg, Pp. 157-161.

Lom, J. (1970) Trichodinid ciliates (Peritrichida: Urceolariidae) from some marine fishes. Folia Parasitologica 17: 113-125.

Loм, J. \& Dyкоva, I. (1992) Protozoan parasites of fish. Elsevier, Amsterdam, 315 pp. 
Madsen, H. C. K., Buchmann, K. \& Mellergaard, S. (2000) Trichodina sp. (Ciliophora: Peritrichida) in eel Anguilla anguilla in recirculation systems in Denmark: host-parasite relations. Disease of Aquatic Organisms 42: 149-152. doi: 10.3354/dao042149

ÖĞüT, H. \& PALM, H. W. (2005) Seasonal dynamics of Trichodina spp. on whiting (Merlangius merlangus) in relation to organic pollution on the eastern Black Sea coast of Turkey. Parasitology Research 96: 149-153. doi: 10.1007/s00436-005-1346-2

ÖĞÜT, H. \& Altuntaş, C. (2011) Monthly variation in the morphological characteristics of Trichodina sp. (Ciliophora: Peritrichida) found on whiting Merlangius merlangus euxinus. Revista de Biologia Marina y Oceanografia 46: 269-274. doi: 10.4067/S071819572011000200017

ÖĞüT, H. \& ÇAvus, N. (2014) A comparison of ectoparasite prevalence and occurrence of viral haemorrhagic septicemia virus (VHSV) in whiting Merlangius merlangus euxinus. Revista de Biologia Marina y Oceanografia 49: 91-96. doi: 10.4067/S071819572014000100010

Özer, A. (2000) The occurrence of three species of Trichodina (Ciliophora: Peritrichia) on Cyprinus carpio in relation to culture conditions, seasonality and host characteristics. Acta Protozoologica 39: 61-66.

Özer, A. (2003a) The occurrence of Trichodina domerguei Wallengren, 1897 and Trichodina tenuidens Faure-Fremiet, 1944 (Peritrichia) on three-spined stickleback, Gasterosteus aculeatus L., 1758 found in a brackish and freshwater environment. Acta Protozoologica 42: 41-46.

Özer, A. (2003b) Trichodina domerguei Wallengren, 1897 (Ciliophora: Peritrichia) infestations on the Round Goby, Neogobius melanostomus Pallas, 1811 in relation to seasonality and host factors. Comparative Parasitology 70: 132-135. doi: 10.1654/4073

Özer, A. (2007) Trichodina modesta Lom, 1970 (Ciliophora: Peritrichia) infestations of an endemic toothcarp Aphanius danfordii Boulenger, 1890 (Pisces: Cyprinodontidae) in Sinop, Turkey. Journal of Natural History 41: 2543-2549. doi: 10.1080/00222930701739724

Özer, A. \& Erdem, O. (1998) Ectoparasitic protozoa fauna of the common carp (Cyprinus carpio L., 1758) caught in the Sinop region of Turkey. Journal of Natural History 32: 441-454. doi: 10.1080/00222939800770231

Özer, A. \& Erdem, O. (1999) The relationship between occurrence of ectoparasites, temperature and culture conditions; a comparison of farmed and wild common carp (Cyprinus carpio L., 1758) in the Sinop region of northern Turkey. Journal of Natural History 33: 483-491. doi:10.1080/002229399300209

Özer, A. \& Ö̈zTüRK, T. (2004) Trichodina puytoraci Lom, 1962 and Trichodina lepsii Lom, 1962 (Peritrichida: Ciliophora) infestations on mugilids caught at the Black Sea coast of Sinop in Turkey. Turkish Journal of Zoology 28: 179-182.

Özer, A. \& Yilmaz KIrCA, D. (2013) Parasite fauna of Golden Grey Mullet Liza aurata (Risso, 1810) collected from Lower Kızılırmak Delta in Samsun, Turkey. Helminthologia 50: 269-280. doi: 10.2478/s11687-013-0140-4

ÖZtürk, T. \& ÇAм, A. (2013) Trichodinid parasites (Protozoa: Ciliophora: Peritrichida) of invasive gobiid fish inhabiting the Lower Kizılırmak Delta in Samsun, Turkey. Pakistan Journal of Zoology 45: 1517-1524.

ÖZtüRK, T. \& Özer, A. (2007) Trichodinid fauna of the toothcarp Aphanius danfordii (Boulenger, 1890) (Osteichthyes: Cyprinodontidae), an endemic fish from Sarıkum Lagoon Lake in Sinop (Turkey). Acta Protozoologica 46: 73-80. 
ÖZtüRK, T. \& Özer, A. (2008) Parasitic fauna of the flounder, Platichthyes flesus L., 1758 caught in the Sarıkum Lagoon Lake in Sinop (Turkey) and the occurrence of parasites in relation to host factors. Journal of Fisheries Sciences.com 2: 403-418.

Pádua, S. B., Martins, M. L., Carraschi, S. P., Cruz, C. \& Ishikawa, M. M. (2012) Trichodina heterodentata (Ciliophora: Trichodinidae): a new parasite for Piaractus mesopotamicus (Pisces: Characidae). Zootaxa 3422: 62-68.

Pickering, A. D. (1977) Seasonal changes in the epidermis of the brown trout, Salmo trutta (L.). Journal of Fish Biology 10: 561-565.

Pickering, A. D. \& Christie, P. (1980) Sexual differences in the incidence and severity of ectoparasitic infestation of the brown trout, Salmo trutta (L.). Journal of Fish Biology 16: 669-683.

RaAbe, Z. (1959) Urceolariidae of gills of Gobiidae and Cottidaefrom Baltica Sea. Acta Parasitologica Polonica 7: 441-452.

Su, X. \& White, R. W. G. (1995) Trichodinid parasites (Ciliophora, Peritricha) from the gills of some Australian marine fishes. Systematic Parasitology 32: 53-59. doi: 10.1007/ BF00009467

TANG, F. \& ZHAO, Y. (2013) Record of three new Trichodina species (Protozoa, Ciliophora) parasitic on gills of freshwater fishes from Chongqing, China. African Journal of Microbiological Research 7: 1226-1232. doi: 10.5897/AJMR12.1163

TÜIKK. Fishery Statistics. Turkish Statistical Institute, Ankara. http://www.tuik.gov.tr [Accessed on 01/09/2014]

Urawa, S. (1992) Trichodina truttae Mueller, 1937 (Ciliophora: Peritrichida) on juvenile Chum salmon (Onchorhynchus keta): pathogenicity and host-parasite interactions. Gyobyo Kenkyu 27: 29-37.

$\mathrm{X}_{U}, \mathrm{~K}$. (2007) Trichodinid ectoparasites (Ciliophora, Peritrichia) from the Tiger puffer Takifugu rubripes in the Yellow Sea, with revision of Trichodina jadranica Raabe, 1958. Acta Protozoologica 46: 311-324.

Valladão, G. M. R., Gallani, S. U., Pádua, S. B., Martins, M. L. \& Pilarski, F. (2013) Trichodina heterodentata (Ciliophora) infestation on Prochilodus lineatus larvae: a host-parasite relationship study. Parasitology 141: 662-669. doi: 10.1017/ S0031182013001480

Van As, J. G. \& Basson, L. (1989) Further contribution to the taxonomy of the Trichodinidae (Ciliophora: Peritrichida) and a review of the taxonomic status of some fish ectoparasitic trichodinids. Systematic Parasitology 14: 157-179. doi: 10.1007/BF02187051

Yemmen, C., Quilichini, Y., Katari, M. H., Marchand, B. \& Bahri, S. (2010) Morphological, ecological and histopathological studies of Trichodina gobii Raabe, 1959 (Ciliophora: Peritrichida) infecting the gills of Solea aegyptiaca. Protistology 6: 258-263.

Yemmen, C., Katari, M. H. \& Bahri, S. (2012) Parasitofauna of some mugilid and soleid fish species from Tunisian lagoons. Acta Adriatica 52: 173-182.

ZaIKA, V. E. (1966) On the fauna of the protozoan parasites of fishes of the Black Sea. Pp. 24-31. In: Vodyanitsky, V. A. (ed.): Helminthofauna zhivotnih yuzhnih morey. Naukova Dumka, Kiev. [in Russian]

Revised version received October 27, 2014, accepted February 20, 2015, published May 29, 2015 